\title{
Influence of Systematic Risk and Persistence to Earnings Response Coefficient with Corporate Social Responsibility as Moderating Variable: The Case on Oil Plantation Company in Indonesia and Malaysia
}

\section{Narumondang Bulan Siregar and Azhar Maksum}

Department of Accounting, Faculty of Economic and Business, Universitas Sumatera Utara, Indonesia

\section{Abstract}

This research aims to analyze the impact on Systematic Risk, Persistence on Earnings Response Coefficient with Corporate Social Responsibility as moderating variables of all the Oil Plantation companies listed in Indonesia Stock Exchange and Malaysian

Corresponding Author: Narumondang Bulan Siregar naru.siregar@gmail.com

Received: 29 August 2018 Accepted: 18 September 2018 Published: 11 November 2018

Publishing services provided by Knowledge

(c) Narumondang Bulan Siregar and Azhar Maksum. This article is distributed under the terms of the Creative Commons

Attribution License, which permits unrestricted use and redistribution provided that the original author and source are credited.

Selection and Peer-review under the responsibility of the ICOI-2018 Conference Committee.
Stock Exchange from 2012 to 2016. There are many oil plantation companies that had breached business ethics and environmental harassment. This research is conducted on plantation companies because the they have certain characteristics, both in terms of magnitude of the required investment and the risks and responsibilities to the environment and community. The population of this research is 14 companies that are listed in Indonesia Stock Exchange and 35 companies listed on Malaysia Stock Exchange during 2012-2016. This research uses absolute residual to analyze moderating variables. The results of this research are that Earnings Persistence partially affects the Earnings Response Coefficient (ERC) significantly, Corporate Social Responsibility can moderate the relationship between Systematic Risk, Earning Persistence, and ERC.

Keywords: systematic risk, earning persistence, corporate social responsibility, Earnings Response Coefficient (ERC)

\section{Introduction}

This research aims to investigate the process of investment decision at the company's level that is generally shown to have a multi-criteria process considering numerous factors into account. There are economic and risk factors, but also the political and social environment and government regulations [5]. An entity in operating its business is inseparable from the community and the surrounding environment, resulting in a 
mutual relationship between the community and the company. Therefore, the company needs positive response from the community gained from what the company did to its stakeholders, including the community and its environment. [6]

From the economic perspective, profit is one of accounting information that is still a major concern for investors. Profit information reflects one of the factors affecting the stock price. If investors have the perception that financial information has a high degree of credibility, then investors will be stuck on the financial statements. This shows that the value of Earnings Response Coefficient (ERC) is high. The reactions given depend on the profit information issued by the company.

According to Scott (2009), ERC is used to measure abnormal return level of securities in response to unexpected earnings components of which the relevant company reported. The strong market reaction to earnings information will be reflected by the high ERC and vice versa [15]. Previous research has found that earnings response coefficients vary by cross-section. Some of the identified factors influence the behavior of earnings response coefficients, such as systematic risk (Lippe, 1990) and social disclosure [15]. Research on earnings response coefficient is often done and have different research results. Palupi (2006) and Perdani (2009) found that earnings response coefficient was influenced by systematic risk and earnings persistence with positive influence. Ambarwati (2008) found that systematic risk (beta) negatively affect earnings response coefficient.

This study focuses on the effect of systematic risk and earnings persistence. Systematic risk consists of market risk and political risk, such as Regulatory Quality, Rule of Law and Control of Corruption. Systematic risk is a risk associated with changes that occur in the market as a whole is selected in this study because investment has high uncertainty (Tandelilin 2010), it is a necessary consideration for investors in making investments. Further research conducted by Tiolemba (2008) showed that systematic risk (beta) negatively affect earnings response coefficient. Susanto's (2012) study indicated a growing opportunity and systematic risk of shares having a significant effect.

Earnings persistence is an ability of a company in maintaining their profit from occasionally and not only because of a particular event (Delvira, 2013).Persistence in this study is important because considering that investment is an activity to gain profit from companies, it is a necessary consideration for investors in making investments based on the company's track record and one of them is through earnings persistence. Scott (2009) said that the higher the persistence of earnings are, the higher the earnings response coefficient (ERC) will be. 
Corporate Social Responsibility (CSR) is a global concept that is currently extremely popular in the business world. Among the companies from all branches, the largest influence of macroeconomic factors on investment decision process is reflected by the financial services companies and the largest influence of legal factors on investment decision process - by the agricultural companies. (Piotr Bialowolski and DorotaWeziakBialowolska).

Environmental factors, especially in palm oil plantation companies have been contemplated in terms of quality of profit. The importance of CSR in developing countries has been discussed by several authors. One study of Asian companies (Belal 2001) argued that developing countries are concerned about foreign investment bringing potential dangers, industrial development, showing adverse environmental impacts and social ills. Rais and Goedegebuure (2009) and Chambel (2007) their research in developing countries have highlighted that globalization encourages CSR in developing countries and The National Business Systems Structure in particular, the political, financial, educational and cultural backgrounds of CSR in multinational companies.

From the different results of the aforementioned research, researcher concluded to make this study which examines the effect of systematic risk, earnings persistence by adding CSR as a moderating variable to earnings response coefficient. The research was conducted on Indonesian and Malaysian Oil Palm plantation companies listed on Indonesia Stock Exchange and Malaysia.

\section{Literature Review}

\subsection{Earnings respond coefficient (ERC)}

ERC is a coefficient that measures the response of abnormal returns of securities to unexpected accounting earnings of firms that issue securities. This coefficient is unexpected earnings against cumulative abnormal return (CAR), which is addressed through slope coefficient in the regression of abnormal return of stock with unexpected earnings. ERC is CAR reaction to earnings announced by the company. The reactions given depend on the quality of profits generated by the company. Whether it is high or low depends on the 'good news' or 'bad news' of the profit. There are several things that cause different market responses to earnings, which are profit persistence, beta, corporate capital structure, profit quality, opportunity growth, and informativeness of price [17]. The value of the earnings response coefficient is predicted to be higher if 
the firm's earnings are more persistent in the future. Likewise, if the quality of the better the profit, the predicted value of earnings response coefficient will be higher.

\subsection{Systematic risk}

Systematic risk is a risk associated with conditions that occur in the market, so many factors which affect it, and beside it there is unsystematic risk and one of that is political risk. Political risks that affect investment decisions include Regulatory Quality, Rule of Law and Control of Corruption

\subsection{The effect of systematic risk on profit response coefficients}

Empirically Collins and Kothari (1989) proved that systematic risk was negatively associated with the earnings accounting response coefficient. Easton Zmijewski (1989) also used systematic risk (beta) as a proxy for variation between firms in his research. Investors will reduce the level of risk it received by considering the specific risk of a company in its investment decision. Investors will assess current earnings to predict future earnings and returns. If the future return is increasingly risky, then the reaction of investors to unexpected earnings of the company will be lower. In other words, if beta gets higher, the earnings response coefficient will be lower [17]. This happens because investors think that profit is an indicator of earning power and return in the future.

\subsection{Earning persistence}

Earnings Persistence is a condition where the current is a reflection of the future period or the present period. This conception is sometimes discussed in a sustainable context, that is, high-quality financial reporting used as a synonym for persistence [16]. The earnings persistence reflects the quality of the firm's earnings and suggests that the firm can retain earnings over time and not only because of a particular event.

\subsection{Effect of earning persistence on earning response coefficient}

Accounting profit is persistent because it can be utilized as an indicator to measure the profit of the next period so it can be useful for investors to make investment decisions [1]. Research Palupi (2006) concluded that earnings persistence correlated positively 
with earnings response coefficient. The statement is corroborated by Mulyani et al. (2007) and also Ambarwati's (2008) research with consistent results.

\subsection{Corporate social responsibility}

Gelb and Zarowin in Adhariani (2005) suggested that the relationship between the extent of voluntary disclosure and earnings response coefficients may be positive or negative. The result will be positive if the company that reveals a lot of information is a company that has good news, and Basu (1977) found that good news firms have more persistent earnings and higher earnings response coefficient. However, there is a negative effect possibility, because the reduced uncertainty due to the increased area of the voluntary disclosure will affect the informative declining of earnings. In other words, investors will base future earnings predictions on information provided on corporate social disclosure.

\subsection{Systematic risk and earning persistence moderated by corporate social responsibility}

Belkaoui and Karpik (1989) showed that there was a relationship between social information disclosure and systematic risk. The higher the political costs are, the more cost the companies will incur to disclose CSR information so that reported earnings are lower (Scott 1997). The earnings persistence reflects the quality of the firm's earnings and suggests that the firm can retain earnings over time and not just because a certain event Scott (2009), For the stability of profit companies must have a harmonious relationship with the environment, especially in plantation companies that have many social problems.

\subsection{The frame of conceptual}

\section{Hypothesis}

$\mathrm{H}_{1 .}$ There is a significant positive association between Beta Risk to Earning Response Coefficient.

$\mathrm{H}_{1 \cdot 2.1}$ There is a significant positive association between Regulatory Quality to Earnings Response Coefficient. 


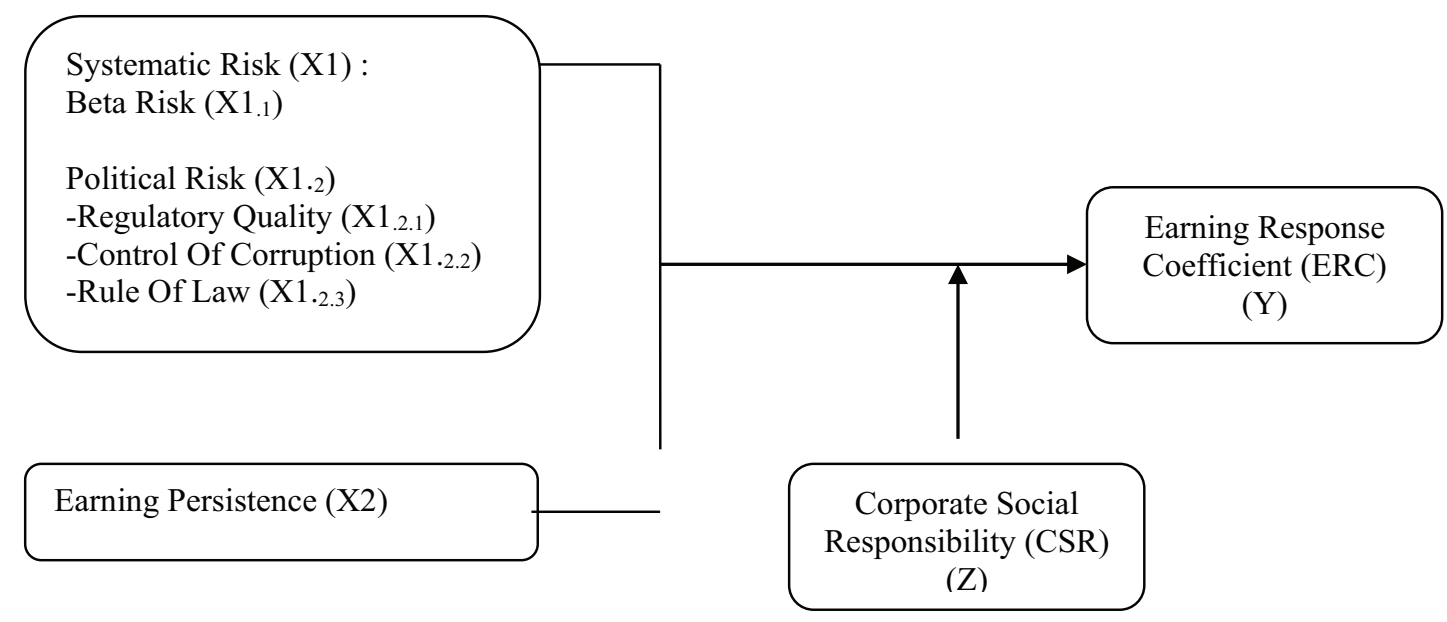

Figure 1

$\mathrm{H}_{1.2 .2}$ There is a significant positive association between Control Of Corruption to Earnings Response Coefficient.

$\mathrm{H}_{1.2 .3}$ There is a significant positive association between Rule Of Law to Earnings Response Coefficient.

H.2. There is a significant positive association between Earning Persistence to Earnings Response Coefficient.

H3. Corporate Social Responsibility as moderating variable can moderate the relationship between of Systematic Risk and Earning Persistence to Earning Response Coefficient Profit.

\section{Research Method}

\subsection{Data and sample selection}

This research populations are 15 companies that are listed on the Indonesian Stock Exchange and 40 companies that are listed on Malaysia Stock Exchange from 2012 to 2016. The financial reports and annual reports of Oil Plantation companies were obtained from www.idx.co.id and www.bursamalaysia.com/market. The total sample of this study amounted to 26 companies where the observation period of research for five years, so the total observation is 130 .

Regulatory Quality, Rule of Law and Control of Corruption are obtained from Political Risk Services International Country Risk Guide. 


\subsection{The measurement of variable}

1. Earnings response coefficient (ERC), is the coefficient $(\beta)$ obtained from the regression between cumulative abnormal return (CAR) and unexpected earnings (EU) as stated in the empirical model:

$$
\mathrm{CAR}_{\mathrm{i}(\mathrm{t} 1, \mathrm{t} 2)}=\beta_{0}+\beta_{1} \mathrm{UE}_{\mathrm{i} . \mathrm{t}}+\mathrm{e}
$$

CAR = Cumulative abnormal return.

UE $=$ Unexpected earnings.

$B=$ Coefficient of regression result (ERC).

$\mathrm{e}=$ error component

2. (a) a. Systematic risk

Market risk is denoted by $\beta$ (beta). Systematic risk affects all companies and therefore

$$
\beta=\frac{N \sum R m \cdot R i-\left(\sum R m\right)\left(\sum R i\right)}{N \sum R m^{2} \cdot\left(\sum R m\right)^{2}}
$$

cannot be eliminated by diversification.

$\mathrm{Rm}=$ market return $\mathrm{Ri}=$ Investment return

$N=$ Total Period

(b) Political Risk, such as Regulatory Quality, Rule of Law and Control of Corruption, using Political Risk Index from Political Risk Services International Country Risk Guide.

3. Profit Persistence is measured by using regression coefficients of regression between current period earnings and future earnings period.

$$
\text { Xit }=\alpha+\beta \text { Xit-1 }+
$$

Xit = company's profit $\mathrm{i}$ in the year of $t$

Xit-1 = company's profit $\mathrm{i}$ in the year of $t-1$

$\beta=$ yield coefficient

4. Corporate Social Responsibility (CSR) to measure corporate social responsibility disclosure uses tools that measure CSR implementation scores, based on the Global Reporting Initiative. (GRI):

$$
\mathrm{CSRD}=\mathrm{V} / \mathrm{M}
$$


CSRD = Corporate disclosure index.

$V=$ The number of items actually revealed by the company.

$M=$ The number of goods expected to be disclosed by the company.

\section{Result}

Moderating Test with an Absolute Difference Method

TABLE 1: Model Summary. ${ }^{b}$

\begin{tabular}{|l|c|c|c|c|c|}
\hline Model & R & R Square & $\begin{array}{c}\text { Adjusted R } \\
\text { Square }\end{array}$ & $\begin{array}{c}\text { Std. Error of } \\
\text { the Estimate }\end{array}$ & $\begin{array}{c}\text { Durbin- } \\
\text { Watson }\end{array}$ \\
\hline 1 & $0.663^{a}$ & 0.440 & 0.413 & 11.22808 & 0.147 \\
\hline
\end{tabular}

The result of coefficient of determination shows that the value of $R$ square is 0.440 , this means that the ERC variable can be explained by independent variable of $44 \%$, while the remaining $56 \%$ is explained by another variable that is not examined.

TABLE 2: ANOVA. ${ }^{a}$

\begin{tabular}{|l|c|c|c|c|c|}
\hline Model & $\begin{array}{c}\text { Sum of } \\
\text { Squares }\end{array}$ & Df & $\begin{array}{c}\text { Mean } \\
\text { Square }\end{array}$ & F & Sig. \\
\hline 1 Regression & 12175.16 & 6 & 2029.193 & 16.096 & $0.000^{b}$ \\
\hline Residual & 15506.57 & 123 & 126.07 & & \\
\hline Total & 27681.73 & 129 & & & \\
\hline
\end{tabular}

Table 2 shows that $\mathrm{F}$ count is greater than $\mathrm{F}$ table and significance value $(0.00<$ 0.005), then the regression model can be used to predict ERC.

TABLE 3: Coefficients.

Model
(Constant)
Zscore (X1.1) Beta
Risk
Zscore (X1.2.1)
Regulatory Quality
Zscore (X1.2.2) Rule
Of law
Zscore (X1.2.3)
Control Of
Corruption
Zscore (X2) Earning
Persistence
AbsX1_X2

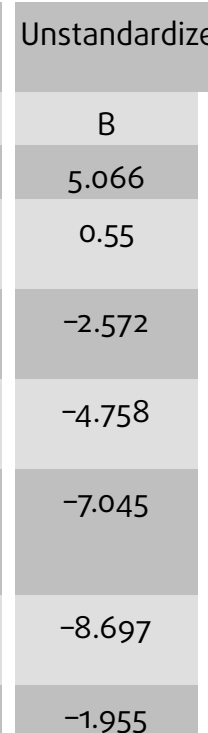

\begin{tabular}{c}
\hline $\begin{array}{c}\text { Standardized } \\
\text { Coefficient } \\
\text { Beta }\end{array}$ \\
\hline 0.038 \\
-0.176 \\
\hline-0.325 \\
-0.481 \\
\hline-0.594 \\
\hline
\end{tabular}

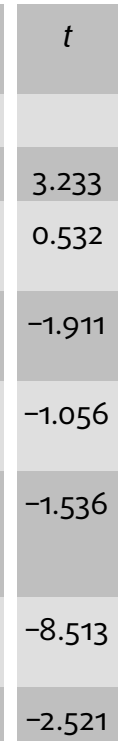

\begin{tabular}{|c|c|c|}
\hline & \multicolumn{2}{|c|}{ Collinearity Statistics } \\
\hline 0.002 & Tolerance & \multicolumn{1}{|c|}{ VIF } \\
\hline 0.596 & 0.915 & 1.093 \\
\hline 0.058 & 0.539 & 1.854 \\
\hline 0.293 & 0.048 & 20.754 \\
\hline 0.127 & 0.046 & 21.535 \\
\hline 0 & 0.936 & 1.068 \\
\hline 0.013 & 0.78 & 1.281 \\
\hline
\end{tabular}


From the table shows that the results of Systematic Risk have significant effect on ERC, (H1 rejected). The results of this research are similar to Ambarwati (2008) Palupi (2006), Tiolemba (2008) and Perdani (2009), but different from Susanto's (2012) research. Profitability influences significantly, ( $\mathrm{H}_{2}$ approved), this result is similar to Scott (2009) and Palupi's (2006) research. We can see from the Sig. table that the value of Significant from AbsX1_2 can moderate the relationship between Systematic Risk and Earning Persistence to Earning Response Coefficient, and it shows the value is 0.013 . The table shows that the value of Beta is -0.193 and it negative value, it means that CSR from the company can't applied totally until 100\%, and we can see it from the main data and it will give the effect to the value of Beta but it still can moderate.

\section{Discussion}

The earnings response coefficient is an inverse function of systematic risk, and in various models, there is an empirical relationship between risk and profit variables [11]. Systematic risk is a risk that cannot be eliminated by diversification in share investment (Husnan, 2000: 161). Investors will reduce the level of risk they receive and consider the specific risks of a company in its investment decision. Low-risk corporate shares will have high earnings response coefficients. Likewise, on the contrary, stock companies that have a high risk will have a low-profit response coefficient.

Sayekti et al. (2007) examined the effect of Corporate Social Responsibility disclosure level - CSR in annual reports on earnings respond coefficient. The result of this study indicated that investors appreciated the CSR information disclosed in the company's annual report. The research that examined the effect of disclosure in the annual report on earnings response coefficient is also done by Widiastuti (2002). This study did not show consistent results with the prediction of voluntary disclosure negatively affected the earnings response coefficient. Nevertheless, empirical testing instead found a significant positive effect of the voluntary disclosure area of the earnings response coefficient

Based on an analysis of data from the Organization of Agriculture and United Nation Food University, found that $55-59 \%$ expansion of palm oil in Malaysia and at least $56 \%$ in Indonesia victimize forest. Because palm oil plantations biologically afflict woods, so the researchers recommend prohibiting expansion in the future if the companies are not attentive to their problems. Therefore, this research intends to fill the gap by analyzing CSR in two ASEAN countries, namely Malaysia and Indonesia. Malaysia and 
Indonesia are chosen because they are regarded as the best country that implement and disclosure CSR compare to other ASEAN countries. [18]

The next research is recommended that researchers pay attention to other factors that affect the ERC as one of the investor's considerations in making investment decisions and increase the number of years of observation and wider type of the company, so the results can be generalized.

\section{Conclusion}

Based on the results of the analyze and discussion that have been proposed, the conclusion of this research are Systematic Risk have no significant effect, but investors pay more attention to the company's ability to earn long-term stability in earnings. In order to maintain profit in the long run, the concern for the continuity of the company should be a priority for investors. Persistence partially affect the Earnings Response Coefficient (ERC) significantly. Corporate Social Responsibility can moderate the relationship between Systematic Risk and earning persistence to ERC. Corporate Social Responsibility is a global concept that is extremely popular in the business world, especially to the Oil Plantation Company because environmental factors have been taken into consideration in terms of quality of profit.

\section{Funding}

This research is supported by Universitas Sumatera Utara (USU) under the research grant Non-PNBP USU 2018.

\section{References}

[1] Ambarwati, Sri,2008, "Earnings Response Coefficient",JurnalAkuntansi, Vol.7,No.2, page.128-134.

[2] Belal, A \&Momin, M 2009, Corporate social reporting (CSR) in emerging economies: A review and future direction', Accounting in Emerging Economies (Research in Accounting in Emerging Economies, Volume 9), Emerald Group Publishing Limited, vol. 9, pp. 119-43

[3] Belal, A \&Momin, M 2009, Corporate social reporting (CSR) in emerging economies: A review and future direction', Accounting in Emerging Economies (Research in 
Accounting in Emerging Economies, Volume 9), Emerald Group Publishing Limited, vol. 9, pp. 119-43

[4] Campbell, JL 2007, Why would corporations behave in socially responsible ways? An institutional theory of corporate social responsibility', The Academy of Management Review ARCHIVE, vol. 32, no. 3, pp. 946-67.

[5] Enoma, A., and I. Mustapha. (2010). Factor analysis of investment decision in Nigerian insurance companies. Interdisciplinary Journal of Contemporary Research in Business, 2(8), 108-120.

[6] Kamil, Ahmad dan Antonius Herusetya. 2012. Pengaruhkarakteristik Perusahaan terhadapLuasPengungkapanKegiatan Corporate Social Responsibility. Jurnal Media RisetAkuntansi.Vol 2, No. 1.

[7] Mulyani, Sri., Nur F. Asyik, dan Andayani, 2007, "Faktor-faktor yang MempengaruhiEarnings Response Coefficient pada Perusahaan yang Terdaftar di Bursa Efek Jakarta", Jurnal Akuntansi dan Auditing Indonesia, Vol. 11, No. 1, hal.35-45.

[8] Lipe, Robert. 1986. "The Information Contained in the Components of Earnings." Journal of Accounting Research, Vol. 24 : 37-54.

[9] Muljono. 2002. "Analisis Faktor-Faktor yang Mempengaruhi Risiko Sistematis. Tesis. Universitas Diponegoro. Yogyakarta.

[10] Murtanto. 2006. "Menciptakan NilaiTambah Melalui Corporate Social Responsibility"

[11] Naimah, Zahroh. 2008. "PengaruhResiko Perusahaan danLeverage terhadap Relevansi Nilai Laba Akuntansi".

[12] Palupi, Margaretta Jati, 2006, "AnalisisFaktor-faktor yang Mempengaruhi Koefisien Respon Laba: BuktiEmpirispada Bursa Efek Jakarta", JurnalEkubank, Vol. 3, hal.9-25.

[13] Piotr Bialowolski and DorotaWeziak-Bialowolska, External Factors Affecting Investment Decisions of Companies

[14] Rais, S \&Goedegebuure, RV 2009, Corporate social performance and financial performance. The case of Indonesian firms in the manufacturing industry', Problems and Perspectives in Management, vol. 7, no. 1, pp. 224-34.

[15] Sayekti, Yosefa \&Ludovicussensiwondabio. 2007. Pengaruh CSR Disclosure terhadapEarning Response Coefficient.

[16] Schipper, K., \& L. Vincent. 2003. Earnings Quality. Accounting Horizons. Vol.70.Supplement: 97-110.

[17] Scott, William R. 2000. Financial Accounting Theory, $2^{\text {nd }}$ edition, Prentice-Hall Canada Inc., Scarborough, Ontario 
[18] Sharma, Asha. 2013. A Comparative Analysis of Traditional Measures of Financial Performance and Economic Value Added 